\title{
INTERPRETIVE COMPILATION OF BEDROCK GEOLOGY OF THE SLAVE CRATON
}

\author{
Mike Stubley \\ Stubley Geoscience, Canada
}

\section{INTRODUCTION}

This poster presents a progress snapshot of an ongoing project, supported by Diamondex Resources Ltd., to compile the bedrock geology of the Archean Slave craton and parts of adjacent Proterozoic orogens. Unlike other published compilations (Hoffman \& Hall, 1993; Fyson \& Hearn, 2001), the current project integrates satellite and geophysical data with published bedrock maps, allowing generation of new data and reinterpretation of geological relationships. Extensive fieldwork has been conducted to investigate critical or anomalous relationships.

\section{DATABASE}

The compilation is maintained within ArcView GIS 3.2a, and has been successfully integrated into other GIS platforms. All data is projected to Universal Transverse Mercator (UTM) Zone 12 using North American Datum 1983 (NAD83). Attribute labels and other text are designed for optimal presentation at $1: 250,000$ scale. However, the accuracy of geological relationships reflects the source data. Many areas are valid at scales of 1:30,000 or 1:50,000, but moredetailed source data are simplified prior to incorporation.

\section{DATA SOURCE}

As of January 2003, approximately $65 \%$ of the exposed Archean craton has been reviewed. Principal data sources include published geological maps $(\mathrm{n} \approx 100)$ and aeromagnetic images. Satellite data, digital elevation models, and aerial photographs have aided lineament analysis. The accessibility of modern highresolution aeromagnetic data, such as has been compiled by Armstrong and Kenny (2001), has been particularly effective in resolving faults and diabase dykes, and also for subdivision of granitoid terranes. Geological maps that include outcrop boundaries are amenable to significant re-interpretation with access to modern geophysical data that was unavailable to the original mappers. Small-scale maps generally lack outcrop information and, hence, re-interpretation of geological contacts has been restrained in the compilation. To date, emphasis has been on data entry and geological interpretation rather than quantitative spatial analyses.

\section{CuRRENT StATUS}

Bedrock types have been classified into 34 units, including 26 for Archean rocks. More than 4000 polygons (averaging $\sim 37 \mathrm{~km}^{2}$ for Archean units) have been assigned descriptive attributes. Linear data includes faults, dykes, and topographic lineaments. Faults, defined and probable (many with displacement sense specified), are extracted from published maps and, more commonly, are interpreted from highresolution aeromagnetic images. Approximately 6000 fault segments averaging about $6 \mathrm{~km}$ in length have been digitized. Diabase dykes, some with defined widths, are classified by swarm name or orientation and whether mapped in outcrop or inferred from geophysics. Approximately 11,000 dyke segments averaging about $3.8 \mathrm{~km}$ in length contribute to the current database. Topographic lineaments (ca. 4000, averaging $\sim 4.3 \mathrm{~km}$ in length) are extracted from satellite imagery and aerial photographs. Point data includes geochronology and kimberlite locations as modified from published databases. Presentation and time constraints have precluded inclusion of individual measurements of structural features and glacial striae.

\section{PRINCIPAL OBSERVATIONS}

The database offers innumerable query possibilities. For diamond explorationists, many of the most pertinent relationships appear to be independent of bedrock type and, instead, are largely based on late fracture systems (faults, lineaments, dykes). The continuity of individual faults, many of which were previously undocumented, is remarkable; numerous faults can be traced for $100-175 \mathrm{~km}$ along strike. The most spectacular fault system, herein termed the Beniah-Napaktulik fault zone (BNFZ), can be traced semi-continuously across the entire Slave craton, from Great Slave Lake in the south to Coronation Gulf in the north (ca. $630 \mathrm{~km}$ ). In the southern craton, the BNFZ appears to demarcate domains with distinctive fracture systems: to the west, principal late faults strike ca. $340^{\circ}$ and $030^{\circ}$ whereas to the east, faults striking ca. $070^{\circ}$ and $045^{\circ}$ predominate. With scrutiny, several other domains or corridors can be envisaged on the basis of fracture patterns, and some of these zones correlate well 
with domains inferred to characterize the upper mantle. A profound spatial association between kimberlite ore and a ca. $30 \mathrm{~km}$-wide corridor of north-northeast striking "Lac de Gras" diabase dykes (Stubley, 2003) is evident in the south and central craton. The compilation clearly demonstrates a link between mantle features and crustal fracture systems.

\section{LIMITATIONS}

The patchy distribution of detailed geological relationships reflects the availability of quality data. Amalgamation of data from sources with various scales and geographic projections, including topographic and hydrologic bases, has introduced spatial errors of $100-$ $200 \mathrm{~m}$ locally. To date, the areal coverage has focussed on regions with known kimberlite occurrences. However, little effort has been expended on interpretation of the kimberlite-rich area at Lac de Gras due to the proprietary nature of much of the best data. Although documentation for all sources of data (maps, geophysical images) forms an integral part of the database, the interpretive nature of the compilation precludes definitive links between geological observations and the final product. In addition, it is difficult to evaluate the influence of personal bias introduced to the compilation. This database is not publicly available and there are currently no plans for publication. Diamondex Resources Ltd. is gratefully acknowledged for the opportunity to display this proprietary information.

\section{REFERENCES}

Armstrong, J.P., Kenny, G., 2001. Slave Magnetics Compilation (SMAC). NWT Geology Division DIAND, Yellowknife, EGS Open Report 2001-003 (8 CD-ROM discs).

Fyson, W.K., Hearn, E.W., 2001. Geology of the Archean Slave Province: a GIS-compatible map. NWT Geology Division - DIAND, Yellowknife, EGS Open Report 2001-04.

Hoffman, P., Hall, L., 1993. Geology, Slave craton and environs, District of Mackenzie, Northwest Territories. Geological Survey of Canada, Open File 2559, scale 1:1,000,000.

Stubley, M.P., 2003. Spatial distribution of kimberlite in the Slave craton: a geometrical approach. $8^{\text {th }}$ International Kimberlite Conference Long Abstract (this volume).

Contact: MP Stubley, 158 Toki Rd., Cochrane, AB, Canada,

T4C 2A2, E-mail: stubley@pathcom.ca 